
ages, such as juices and juice drinks and water products.

\section{THE INTERVIEWER}

The interview was conducted in December 2010 by Sunil Gupta, Edward W. Carter Professor of Business Administration, Harvard Business School, Boston, USA and member of the editorial board of MIR
(Stan Sthamurathan)



Mr. Sthanunathan is currently global Vice President of Marketing Strategy \& Insights of The Coca-Cola Company in Atlanta. Prior to taking on this role, he was Head of Knowledge \& Insights for the Asia Group in Hong Kong.

Stan started his career with The Coca-Cola Company 15 years ago as Research Manager of the Middle East and North Africa Division based in London. Before joining Coca-Cola, he was, for five years, General Manager of TNS in their Middle East, North Africa office based in Dubai.

Stan's research career started in 1985 with Pathfinders:India, with whom he was associated for almost seven years, over which time he achieved the position of General Manager of the agency.

He earned his Bachelor Degree in Mechanical Engineering at the University of Mumbai and followed this with an MBA from India Institute of Management in Bangalore, India.

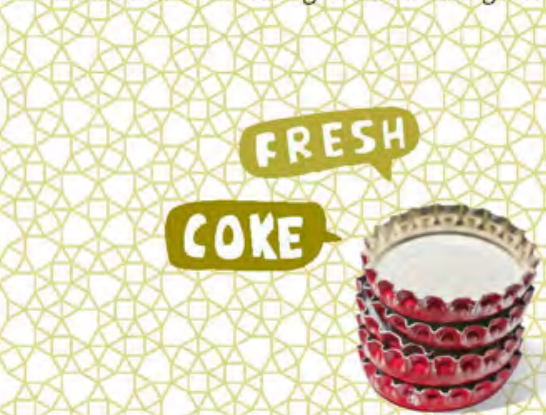




\title{
MIR TALKS TO STAN STHANUNATHAN, VICE PRESIDENT OF MARKETING STRATEGY AND INSIGHTS, COCA-COLA COMPANY
}

\author{
Interview by Sunil Gupta
}

\section{Coke has been successful for the past 125 years and has constantly increased its business. How did one of the most famous companies in the world master the recent economic downturn? How are they handling increasing health consciousness and other trends in consumers' lifestyles? Stan Sthanunathan answers these questions and describes how the Coca-Cola Company is facing the changing world of marketing.}

MIR: Stan, thank you for taking the time to talk to me. Let me start by asking you how the current economic environment has affected Coke. Do people view Coke as a discretionary item that they can avoid buying during tough economic times, or do they think of it as a small luxury to relieve stress in difficult times?

STAN STHANUNATHAN: I believe that everyone looks for small moments of happiness. And items that can provide that happiness, but which are expensive in nature, are the ones that usually get knocked out of the portfolio of things that people buy. As you said, Coke is an affordable luxury, and it is therefore relatively more recession-proof than a lot of other brands. The need for happiness is always there and the brand fits in perfectly.

MIR: So you have not seen any significant dip in your sales or revenues as a result of the economic downturn?

STAN STHANUNATHAN: In certain pockets, yes. But is Coke in the kind of category that would be cut like an IT budget? No! You don't see that kind of dramatic impact, but you do feel certain effects. What we have seen is a change in pack mix more than anything else.
MIR: In what way?

STAN STHANUNATHAN: When people stay at home, they still want to enjoy good entertainment. They might dial for a pizza, or they might cook meals at home, but they still need something to go with it. So, instead of going to a restaurant and ordering a medium-priced or an expensive meal and ordering a drink with it, they have the meal at home, and they still need the drink. Therefore, they tend to buy multiserve packs and multi-packs.

MIR: Some companies, such as Procter \& Gamble, introduced "basic versions" at cheaper prices to manage their brands during this tough economic environment. Has Coke done anything like this?

Stan Sthanunathan: No, we haven't done that. There is one version of Coke. If you go back to what Andy Warhol said many years back, it is a great equalizer —John Kennedy had it, Marilyn Monroe had it, the man on the street has it, and a Coke is a Coke is a Coke.

MIR: The other environmental force that may have had some impact on Coke is the increasing health consciousness among consumers. For example, some schools in the US are banning soda drinks in school vending machines. What has been Coke's reaction to this?

STAN STHANUNATHAN: Our stated policy is very clear. First, we are in the business of providing choice to consumers, and it is the choice of a whole range of beverages. They choose the beverage that suits their needs and lifestyle the best. Second, health and wellness are not a one-dimensional problem. There is an input and an output issue. And if you don't manage both ends, you end up taking one side or the other, which is not a solution to the problem. 
MIR: Indra Nooyi at Pepsi is making a very strong claim about the health focus of Pepsi. Is that something that Coke also aspires to do, or do you see it very differently?

StAN SthanUnathan: As I said, people do need beverages from which they seek functional benefits. But they're also looking for emotional benefits from the products they buy. So you've got to have a balanced portfolio which offers everything that consumers look for.

MIR: So you are a free market person who believes in providing choices and letting consumers make the decision?

StAN Sthanunathan: How can we make decisions for them? Consumers have their own set of circumstances, and they need to make that choice based on what they think is best for that particular occasion. The same person might have one beverage for one occasion and a completely different beverage for another occasion. Our job is to ensure that we make the best possible beverage that they can choose for that particular occasion, based on their needs. Let them make the decision.

MIR: You said earlier that a Coke is a Coke, and that has been the case for 125 years. What have been the major innovations at Coke?

STAN STHANUNATHAN: Go back 10 years, when we probably had four billion-dollar brands. Today, we have 14 billion-dollar brands. That doesn't happen by accident; it happens because there is a lot of emphasis on innovation. I'll give you examples of brands that have become a really big force in various markets. For example, in China we have a brand called Minute Maid Pulpy. If you taste that product you will say that it tastes very good, because it's an orange juice with orange pulp in it. It's a juice drink, though, not $100 \%$ juice. So it is extremely affordable. It's got all the nutritional value of a glass of orange juice. It's got a mouth feel that is like a freshly squeezed orange juice with pulp. And it tastes great. But how do you make that without the pulp settling down and how do you homogenize it? That's a massive innovation. Coke Zero is another big innovation. It's the same Coke taste, with zero calories, and that's a breakthrough in sweeteners.

MIR: Let's move on to marketing, which is certainly one of Coke's main strengths. How has marketing at Coke changed in the last four or five years?

Stan Sthanunathan: Again, the change is driven by how consumers spend their time. Once upon a time, it used to be one brand identity and one brand communication on a global basis. In the late 1990s and early 2000s, it became a little bit of a local/local free-for-all kind of thing. Those were the days when the brand lost momentum. But in the last four years, you'll see that we have had a consistent brand visual



identity. Even during the days of local/local, we didn't change our graphics, and we didn't change our logo. We remained consistent even during that period. And now the brand looks even more similar across all the markets. We have standardized our brand vision and architecture, providing freedom within a framework. So if you go from one market to another, what the brand is saying is very consistent, but it is done in a locally relevant way and it's all about happiness.

The other dimension of change is how we actually connect with consumers. We are in a category of products that are consumed on a daily basis. So we're going to be talking to consumers on a daily basis. And the whole model of putting up 60-second television commercials, and hoping that people remember you as they go and buy the brand, is actually becoming less and less relevant. Therefore, while we do spend a fair amount of money on television advertising, we've also started doing a lot of work in the digital area and, more importantly, the whole area of shopper marketing.

MIR: What specific things have you done in digital marketing?

STAN STHANUNATHAN: Let's take mycokerewards.com in USA. I don't recall the exact numbers, but I think there are close to 15 million people registered on that website. These are people who engage with us on a regular basis. That's one way in which we reinforce the love that they have for the brand. And the Facebook fan page of Coca-Cola, again, has close to 22 million people. If you go to the Coca-Cola fan page on Facebook and you see the kind of stuff that people post, it is incredible. I mean, these are not employees of the company; they are consumers. 
Just yesterday I was looking at a photograph posted by one consumer. He has furnished his entire bedroom with Coke memorabilia, including his bed sheets and pillow covers. Now, that's the level of engagement and passion that people have. If that is not love, what is?

MIR: So you basically provide the platform for consumers to engage with each other?

STAN STHANUNATHAN: No, the platform was not even created by us. It was created by two Hollywood actors. So that's probably the ultimate form of engagement, that's the power of brand because you don't even need to create a fan page. Somebody else will create it for you. We actively participate in that fan page as a brand. We post updates, links and engage in dialog with fans. However, the fan page is of the people, by the people, for the people. Let them do it. And there are occasions when they say nasty things about us, but you've got to be magnanimous enough to listen to that and not get upset. And if it is something that needs to be done, you do it, but don't become defensive.

MIR: Help me understand - why would I want to become a fan of Coke on Facebook?

STAN STHANUNATHAN: You would want to become a fan of Coke on Facebook because you love the brand, and you want to find out how other fans are expressing their love. You go and see the number of photographs posted. Probably that's in the millions. And there are people who take videos of consumption occasions, and there are even people who have made massive artworks that they've posted on Facebook. And you are learning from each of them, finding out how passionate people are.

MIR: You have millions of Coke consumers, and although 22 million Facebook fans sounds like a big number, is it really the tail of the distribution? Are these your typical customers?

STAN STHANUNATHAN: No, I wouldn't ever say that they are representative of our average consumers. We have billions of consumers and we have one billion servings a day. So if you have 22 million Facebook fans, that's not a big proportion of the total consumer base. We work from a relative perspective. How many other brands have 22 million fans, without offering a financial incentive for them to become fans?

MIR: So what do you learn from those 22 million fans?

STAN STHANUNATHAN: We monitor the conversation on an ongoing basis, to see in what dimensions people talk about the brand. We want the number of fans to become bigger, and we want the others who are not such active fans to become like the active fans. Therefore it's important to understand what makes these fans tick. So to us it is also a source of insight.

MIR: Are all your Facebook fans in love with your brand or do you have an equal number of people who are looking for coupons and other rewards?

STAN STHANUNATHAN: I think there are both types of people. You can't stop that. There are some people who are deal hunters. They come and join us because of the deal, and they get good deals. So be it-what can you do?

MIR: But you think the majority are the passionate kind, not the deal kind?

STAN STHANUNATHAN: I don't have an exact answer to that. I don't know how many of them would be the passionate kind, and how many of them would be the deal seeker, because in mycokerewards.com, it is very difficult to sort the two.

MIR: In my experience, senior executives initially get excited about building this kind of a social platform. But very soon, the conversation turns to hard questions and skepticism where people start asking, what does it get me? How much money should I spend on engaging customers and getting Facebook fans? What's the ROI? How do you convince senior management to spend millions of dollars in building a Facebook fan page or mycokerewards.com?

» How many other brands have

22 million fans [on Facebook], without

offering a financial incentive for them

to become fans? «

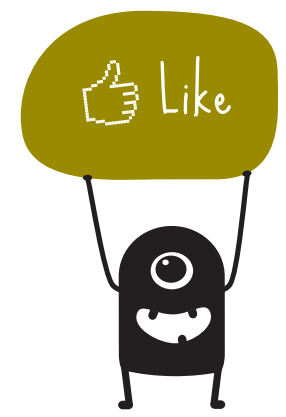


STAN STHANUNATHAN: I Would answer it very differently. If you have a big idea, then your starting point should not be that you want to build a fan page for Coca-Cola. If that's your starting point, it's probably the wrong one. I can tell you right away that it'll be a poor ROI. Take the recent Old Spice social media campaign as an example — that's a really big idea. And I'm absolutely sure that they had a phenomenal ROI on it.

You can't create a fan page and simply ask your consumers to become your fans. What's the reason? Why should they become fans? Do you have a strong brand to begin with? Do you have a great idea? Do you have an engaging web page? Do you have a message that is relevant to people? And I think Old Spice is probably one of the best examples of a brand that had lost its way, and was not strong. They used social media to make it come alive, because they had a big idea. That requires really good, solid marketing genius.

We produced a YouTube video called the happiness machine (http:// www.youtube.com/watch?v=lqT_dPApj9u). The video set the place on fire and has over 3 million views. How much did it cost us? Far less than a 20-second spot on television. But then, it was not just the production of a video. It was a much broader idea. We had a complete, integrated activation plan. So it feeds on itself.

MIR: Once you have this idea, how do you make it go viral?

\section{») You can't create a}

fan page and simply

ask your consumers to

become your fans. «
Stan Sthanunathan: There are billions of videos on YouTube, and that's where your integrated activation is very crucial. If you just put it on YouTube, then you're leaving it to chance. You have to activate it across multiple touch points. I don't know whether you've seen the Old Spice case study that P\&G goes around presenting. I look at it and say, wow, this is brilliant because it actually started as a television idea. Then they took it over through a genuine integrated marketing communication plan. Unless and until you do that it is not going to go viral. It may go viral on its own once in a blue moon, but that is more down to luck.

MIR: So if you were to give a blueprint on how to make this happen, what would you recommend?

Stan sthanunathan: That's like asking for the secret formula. The best way to make that happen, Sunil, is to look at how a typical person spends his or her day. How can you touch this person at different moments during the day, so that you increase the probability of getting noticed in a platform where there can be some mode of interactivity. That will drive the initial launch. If we just put it out there in one touch point and leave it, it will die. Even if we do a massive Super Bowl television commercial, it's not going to get massive traction.

MIR: Talking about Super Bowl, you have done some wonderful things with the Beijing Olympics and the South Africa World Cup. Can you tell us how that came about, and what was your experience with these events?

STAN STHANUNATHAN: Both of them have been enormously successful events for us. Again, there are two or three things that we keep in mind. One, we leverage the scale of the Coca-Cola company because we operate in more countries than most companies in this world. In fact we are present in more countries than there are members of the United Nations. Two, we create a totally integrated communication program. Three, we have an advantage which a lot of other sponsors of these events might not have: the user experience in sponsoring such events. With the Olympics we go back more than 75 years now, and an equally long time with FIFA. So we understand those events and consumer passion surrounding those events. And we do it willingly, efficiently, and effectively, year after year.

MIR: But it seems like you raised the bar with the South Africa World Cup and the K'Naan song.

Stan sthanunathan: Absolutely. And this doesn't happen by accident. Six or seven years ago we started work on the South Africa World Cup, to try and understand the insight that we should be leveraging. First you identify the core insight that you will be leveraging, then your whole idea is built around it, and then you take it forward from there. But if you wake up a year before the World Cup, then it won't work. 
MIR: Let's move from branding and engaging customers to market intelligence. How has market intelligence changed in the last few years?

STAN STHANUNATHAN: I have a slightly controversial point of view on market intelligence and insight. I think the research business as we know it today will become very, very different in the next ten years. The days of asking questions and getting answers are going to become a thing of the past. If I came and told you that I wanted to administer a two-hour-long questionnaire or a one-hour-long questionnaire, how would you react?

MIR: I wouldn't be very happy.

Stan Sthanunathan: Exactly. That's how a lot of people feel. And although that group of people is probably not a majority today, they will be tomorrow. Then it becomes very difficult. Therefore, innovation in the way we go about collecting insight will become extremely important. If you don't think creatively, you could easily land up in a situation where you find that you can't get any insights.

MIR: So what will replace the surveys and the questionnaires?

STAN STHANUNATHAN: There are lots of new things that are out there on the horizon. Active listening, for example. That's where we've been putting a fair amount of money.

MIR: But if you actively listen to your Facebook fans, are you concerned that they are not representative of your typical consumer?

STAN STHANUNATHAN: They're not representative. But there are lots of people who are online and not on our fan page. They are also talking. And we've got people who are talking without being prompted to talk, without being led by suggestive questions or rhetoric questions. So understanding them can actually play a major role in obtaining some core insights.

MIR: Once you start active listening, does it change the way in which you collect and analyze data?

STAN SthanUnathan: Absolutely. While I am a mechanical engineer, and I have a very quantitative bent of mind, I also believe that using the past to predict the future is what losers do. The winners would dream up a future, and take you there.

MIR: That's an interesting thought. So we should not be doing market research at all.

STAN STHANUNATHAN: No, you should be doing a different kind of research. You should not be doing research to analyze the past. But

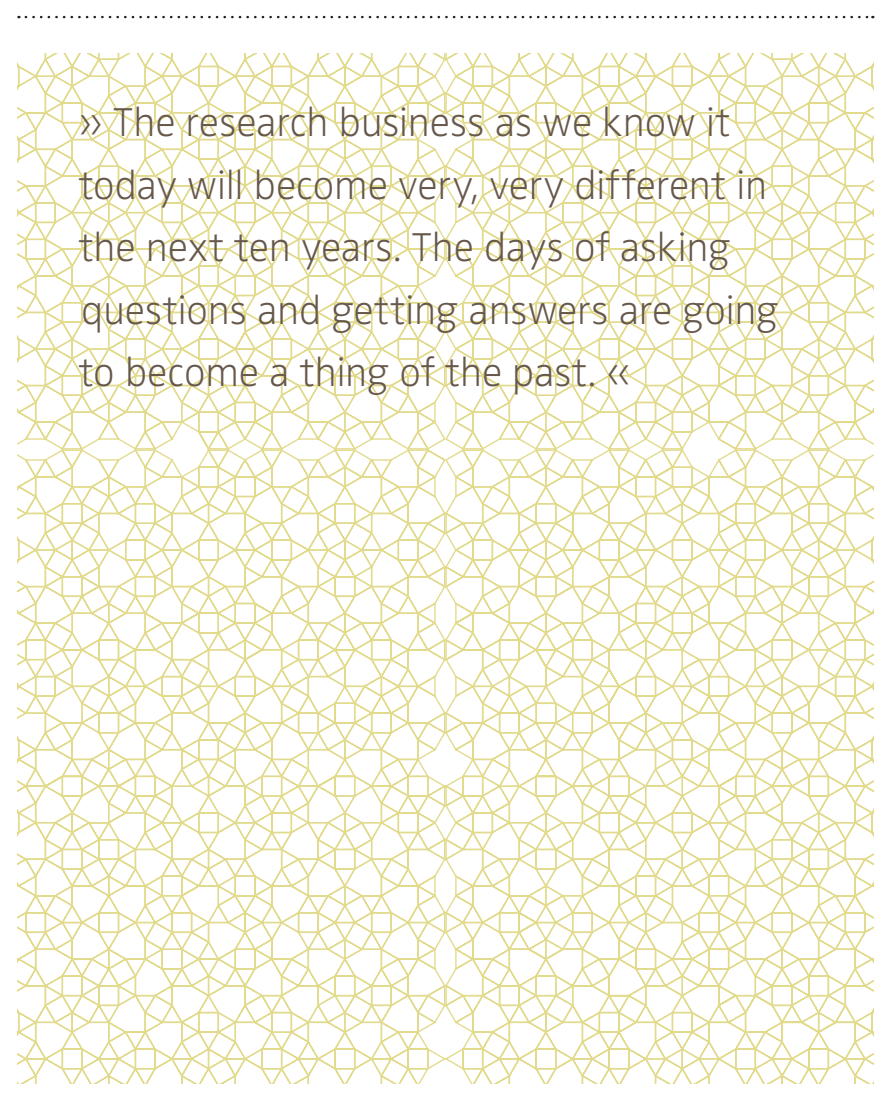

you can learn from the past because you don't want to make the same mistakes multiple times. To the extent that you want to understand what went wrong and what went right, analyze the past. I'm increasingly not using the word "insights" internally. I use words like inspiration and provocation a lot more. That's what I see as my role. If I can't inspire people to elevate their thinking, I've not done my job. If I can't provoke them to take some positions that they would never have taken otherwise, I've failed.

MIR: So does this mean that the kind of reports you get, and the kind of analysis you conduct, are very different from what you did seven or eight years ago?

STAN STHANUNATHAN: Absolutely. We do things periodically to understand if we have actually moved the needle on that dimension. And if you look at our presentations today and compared them with how they used to look four years ago, there are many differences. They are a lot more visual, a lot more storytelling in nature. Be on the edge, don't be afraid. Lean as much as you can, and if you lean forward too far then I'll pull you back...but don't stop leaning. 


\section{») People need to have an ability to strike}

\section{the right balance between art and}

science, gut feeling and fact, points of view and conclusive evidence. «

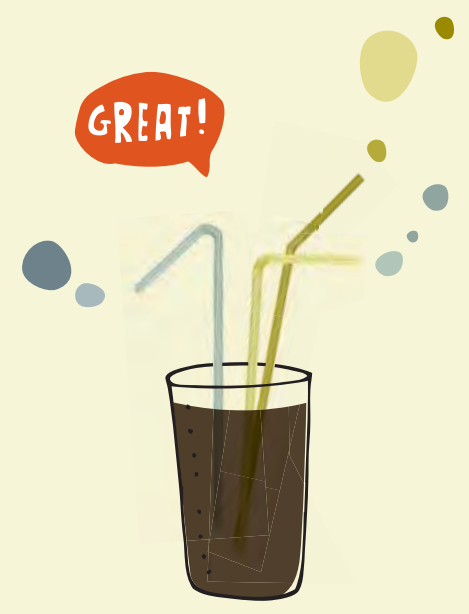

MIR: Is experimentation a big part of what you do now?

STAN STHANUNATHAN: A significant part, I would say. Not the majority. We are experimenting with a lot of new things.

MIR: More than before?

STAN STHANUNATHAN: Oh, much more than before. I have done more experimentation in 2010 than in the seven years before.

MIR: And why is that?

STAN STHANUNATHAN: We continue to explore new avenues for research and analysis and in some cases are employing as yet unproven techniques. But we believe this is how we will push the envelope to find insights that are even more dynamic and useful than what we know works today.

MIR: So if you look at the changing landscape in terms of how marketing is changing, how market intelligence or what you call inspiration and provocation is changing, what are the skills needed for the people who'll succeed in the marketing world tomorrow?

STAN STHANUNATHAN: I think people need to have an ability to strike the right balance between art and science, gut feeling and fact, points of view and conclusive evidence. You might be the best in class in one area, and you do need those kinds of people, but they will become super specialists. But if you want to become a broader marketing person, you need the right blend.

MIR: : Do you hire differently or train differently as a result of this?

STAN STHANUNATHAN: Not everybody, because I do also need experts. When I say that you shouldn't pretend that the past can predict the future, I do have somebody who does that in my team. So I hire people who can make sound predictions for the future based on the past, but I also hire people who sit and dream.

MIR: Stan, thank you very much. I appreciate that you were able to spend some time with me to share your thoughts. Best wishes for the future. • 